Izvirni znanstveni članek/Original article

\title{
Povezave med izbranimi dejavniki tveganja in pojavnostjo bolečine v križu pri zdravstvenem osebju
}

Correlation between selected risk factors and prevalence of low back pain in health care personnel

\author{
Andreja Demšar, Joca Zurc, Brigita Skela-Savič
}

Ključne besede: hrbtenica; bolečina; medicinske sestre; zdravniki; bolničarji; dejavniki tveganja na delovnem mestu

Key words: spine; pain; nurses; doctors; nursing assistants; work-related risk factors

Andreja Demšar, dipl. m. s.

Kontaktni e-naslov/ Correspondence e-mail: d_andrejka@hotmail.com

doc. dr. Joca Zurc, prof. raz. pouka; Fakulteta za zdravstvo Jesenice, Spodnji Plavž 3, 4270 Jesenice

izr. prof. dr. Brigita Skela-Savič viš. med. ses., univ. dipl. org.; Fakulteta za zdravstvo Jesenice, Spodnji Plavž 3, 4270 Jesenice

Članek je nastal na osnovi diplomskega dela Andreje Demšar: Povezave med izbranimi dejavniki in pojavnostjo bolečine $v$ križu pri zdravstvenem osebju (2014).

\section{IZVLEČEK}

Uvod: Bolečina v lumbalnem predelu predstavlja pogosto zdravstveno težavo med zdravstvenim osebjem. Z raziskavo smo želeli ugotoviti, kako pogosto se bolečine v križu pojavljajo pri zdravstvenem osebju, in sicer v povezavi z izbranimi dejavniki tveganja.

Metode: Raziskava temelji na neeksperimentalni kvantitativni metodi empiričnega raziskovanja. Uporabili smo vprašalnik zaprtega tipa o bolečini v križu, ki ga je izpolnilo 89 zdravstvenih delavcev v Splošni bolnišnici Jesenice in domu upokojencev na področju Gorenjske. Za ugotavljanje statistično značilnih razlik med skupinami smo uporabili test $\chi^{2}$ in enofaktorsko analizo variance.

Rezultati: Bolečina v križu se pri 40,4 \% zdravstvenega osebja pojavlja večkrat na mesec, najpogosteje pri bolničarjih $(p=0,001)$ in zaposlenih na negovalnem oddelku $(p=0,006)$. Povprečno traja manj kot en teden (43,8 \%). Dejavnik, ki je z njo najbolj povezan, je dvigovanje in prenašanje bremen $(\bar{X}=4,5)$. Glede izobraževanj s področja bolečine $\mathrm{v}$ križu in pravilnega dvigovanja bremen obstajajo statistično značilne razlike med poklicnimi skupinami $(p<0,010)$.

Diskusija in zaključek: $Z$ bolečino so najbolj povezani dejavniki, ki nastanejo zaradi neposrednega fizičnega dela s pacientom. Potrebna so nadaljnja raziskovanja na reprezentativnih vzorcih, treba bi bilo izvesti tudi izobraževanja za zaposlene in uvesti nove pripomočke, ki bi jih zdravstveno osebje uporabljalo pri svojem delu s pacientom.

\footnotetext{
ABSTRACT

Introduction: Low back pain is a common health complaint among health care workers. The aim of the study was to identify the prevalence of low back pain among health care personnel in relation to selected risk factors.

Methods: The study is based on a non-experimental quantitative method of empirical research. A close-ended questionnaire on low back pain was used and completed by 89 health care workers at the General Hospital Jesenice and retirement home in the Gorenjska region. A Chi-square and one-way ANOVA were computed to establish statistically significant differences between the groups.

Results: In $40.4 \%$ of respondents low back pain occurs several times a month, mostly among nursing assistants $(p=0.001)$ and those working in nursing units $(p=0.006)$. On average, the pain lasts less than a week (43.8\%). The factor that is most commonly associated with low back pain is lifting and carrying of loads $(\bar{X}=4.5)$. Statistically significant differences were revealed between occupational groups in terms of knowledge on low back pain and correct load lifting techniques $(p<0.010)$.

Discussion and conclusion: Low back pain is most frequently associated with direct physical contact with patients. Further research with larger representative sample size will be required. Education and counselling to prevent low back pain in nurses is recommended along with the use of devices for safe patient handling.
} 


\section{Uvod}

Bolečina $\mathrm{v}$ hrbtenici je najpogostejša diagnoza $\mathrm{v}$ skupini bolezni mišično-skeletnega sistema in veziva. Med bolečinami $\mathrm{v}$ hrbtenici po pogostosti izstopa bolečina v lumbalnem predelu, ki jo imenujemo tudi bolečina v križu. Pojavlja se s pestro klinično sliko, pri čemer je vodilni simptom bolečina (Košak, 2010; Kert, 2012). Bolečina v križu prizadene na milijone ljudi po vsem svetu, skoraj tri četrtine populacije se vsaj enkrat v življenju sreča z njo (van Vuuren, et al., 2005; Klančar \& Kafel Jere, 2009). Težave s križem predstavljajo enega najtežjih in najdražjih zdravstvenih problemov v industrijskih državah (van Vuuren, et al., 2005), saj so bolečine, zmanjšana gibljivost in nezmožnost obremenjevanja ledvenega dela hrbtenice glavni vzroki prezgodnje delovne nesposobnosti (Stričević, et al., 2006).

Bolečina v križu je opisana kot ena glavnih poklicnih bolezni med zdravstvenim osebjem. Največja razširjenost pojava bolečin $\mathrm{v}$ križu pri zdravstvenem osebju je ravno med medicinskimi sestrami (Karahan, et al., 2009). V poklicu medicinske sestre je še posebej prizadeta starostna skupina od 20 do 40 let (Ramšak, 2000). Raziskave kažejo, da ima kar 77,1 \% medicinskih sester bolečine in poškodbe hrbtenice, sledijo zdravniki $(63,3 \%)$ in negovalno osebje $(53,5 \%)$ (Karahan, et al., 2009).

Dejavnikov za bolečino v križu je veliko, med najpogosteje ugotovljenimi so velike obremenitve hrbtenice, zlasti pri pripogibanju, nošenju in dvigovanju predmetov, težko fizično delo, upogibanje, zvijanje, vlečenje in potiskanje, ponavljajoči se vzorci dela, statični položaji in vibracije (Fortuna \& Kersnič, 2003). Zdravstveno osebje ima zaradi nenehnega dvigovanja in premikanja pacientov veliko možnost poškodb in bolečin v križu (Douglas, et al., 2012).

Prevelike in dolgotrajne obremenitve predstavljajo povečano tveganje za nastanek trajnih poškodb. Zaradi tega mora zdravstveno osebje poznati tehniko varnega in učinkovitega dvigovanja bremen, kar mu pomaga pri vsakodnevnih aktivnostih pri izvajanju negovalnih intervencij (Stričević, et al., 2012). Izobraževalni program znanja in gibalne aktivnosti pri delu oziroma pravilnih tehnik rokovanja s pacientom se je pokazal kot sredstvo zmanjšanja bolečine $\mathrm{v}$ križu na delovnem mestu, $\mathrm{k}$ preventivi bolečine $\mathrm{v}$ križu pa lahko prispeva vsak posameznik sam. Pomembno je, da se vsak, ki že ima težave, zaveda, da jih lahko zmanjša le, če bo pri tem aktivno sodeloval. Slednje vključuje skrb za redno gibalno aktivnost, čim manj obremenjevanja gibal na delovnem mestu in skrb za primerno telesno težo (Bilban \& Djomba, 2007).

\section{Namen in cilji}

Namen raziskave je bil ugotoviti, kakšne težave s križem se pojavljajo pri zdravstvenem osebju in kateri izbrani dejavniki so povezani s prisotnostjo bolečine v križu. Zanimalo nas je tudi, katerih izobraževanj o preventivi pred pojavom bolečine $\mathrm{v}$ križu na delovnem mestu je deležno zdravstveno osebje. Zastavili smo si naslednja raziskovalna vprašanja:

- Kolikšna je prisotnost bolečine $\mathrm{v}$ križu pri zdravstvenem osebju, kot so bolničarji, medicinske sestre in zdravniki?

- Kakšne so povezave med pojavnostjo bolečine v križu pri zdravstvenem osebju in izbranimi dejavniki tveganja?

- Kolikšna je udeležba zdravstvenega osebja na izobraževanjih s področja preventive pred pojavom bolečine v križu?

- Kakšne so razlike v pojavnosti bolečine $\mathrm{v}$ križu med poklicnimi skupinami, starostjo in oddelkom zaposlitve?

\section{Metode}

Raziskava je temeljila na neeksperimentalni kvantitativni metodi empiričnega raziskovanja, podatke smo zbrali s tehniko anketiranja.

\section{Opis instrumenta}

Podatki so bili pridobljeni s pomočjo strukturiranega vprašalnika, ki smo ga razdelili med bolničarje, srednje in diplomirane medicinske sestre in zdravnike. Vprašalnikje bil sestavljen na podlagi pregleda raziskav v svetu (Roupa, et al., 2008; Karahan, et al., 2009) in Sloveniji (Fende, et al., 2009; Stričević, et al., 2012; Zurc, 2012). Vprašalnik je bil anonimen, sestavljen je bil iz dveh vsebinskih delov. Vseh vprašanj je bilo 17, prvih šest vprašanj je spadalo v prvi vsebinski del, ostalih 11 pa v drugi vsebinski del vprašalnika. Prvi del je zajemal demografske podatke (spol, starost, izobrazba, delovno mesto - vrsta oddelka), drugi del pa vprašanja o bolečini v križu (vrsta in narava dela zdravstvenega delavca, pojavljanje bolečine $\mathrm{v}$ križu, dejavniki, ki so povezani s pojavom bolečine $\mathrm{v}$ križu, preventiva bolečine). Test zanesljivosti instrumenta je bil izračunan na podlagi koeficienta Cronbach alfa in je dosegel vrednost 0,723 .

\section{Opis vzorca}

$\mathrm{V}$ raziskavo smo vključili srednje in diplomirane medicinske sestre, bolničarje in zdravnike iz Splošne bolnišnice Jesenice (SBJ) in Doma upokojencev dr. Franceta Bergelja Jesenice (DUFBJ). Izvedli smo kvotni neslučajnostni način vzorčenja. Celotna populacija zaposlenih v SBJ je bila 652 zaposlenih, v DUFBJ pa 141. Končni vzorec anketirancev je vključeval 120 zdravstvenih delavcev (40 bolničarjev iz DUFBJ, 40 srednjih in diplomiranih medicinskih sester ter 40 zdravnikov iz SBJ). Za izbiro oseb v vzorec smo uporabili izločitvene kriterije: delovno mesto (srednja 
in diplomirana medicinska sestra, zdravnik, bolničar), prisotnost na delovnem mestu $\mathrm{v}$ dopoldanskem času, ko je potekalo anketiranje, prostovoljno sodelovanje, omejitev velikosti vzorca glede na populacijo posameznih poklicnih skupin ter oddelek, na katerem so zaposleni (kirurški/ortopedski oddelek, interni/ intenzivni oddelek, negovalni oddelek). Zaradi premajhnega vzorca iz drugih zdravstvenih skupin (npr. fizioterapevti, delovni terapevti ipd.) smo se odločili za tri skupine zdravstvenih delavcev. Od 120 razdeljenih vprašalnikov je bilo izpolnjenih 89 (25 bolničarjev, 40 srednjih in diplomiranih medicinskih sester, 24 zdravnikov), kar predstavlja 72,2-odstotno realizacijo vzorca.

\section{Opis poteka raziskave in obdelava podatkov}

Raziskava je potekala od 17. 4. 2013 do 21. 6. 2013. Pred izvajanjem anketiranja smo pridobili pisno soglasje obeh vključenih zavodov za raziskovanje. Pri izvajanju anketiranja in analizi podatkov je bila zagotovljena popolna anonimnost in varnost pridobljenih podatkov. Vprašalnike $(n=120)$ smo najprej razdelili s posrednim pisnim pristopom prek glavnih medicinskih sester, zaradi nizke odzivnosti zdravnikov pa smo izvedli še drugi krog razdeljevanja vprašalnikov z osebnim pristopom.

Vsi podatki so bili analizirani s statističnim paketom SPSS $20.0 \mathrm{z}$ vidika opisne statistike (povprečne vrednosti, standardni odklon, frekvence, odstotki). Razlike med skupinami v proučevanih spremenljivkah so bile ugotovljene s testom $\chi^{2}$ in enofaktorsko analizo variance (ANOVA), kjer smo za statistično značilne upoštevali vrednosti pri $p<0,050$.

\section{Rezultati}

$\mathrm{Z}$ raziskavo med zdravstvenim osebjem smo ugotovili, da se bolečina $\mathrm{v}$ križu najpogosteje pojavlja pri bolničarjih ter na negovalnih oddelkih in da traja povprečno manj kot en teden. Dejavnika, najbolj povezana $\mathrm{z}$ bolečino $\mathrm{v}$ križu, sta dvigovanje in prenašanje bremen $(p=0,274)$. Seminarji in izobraževanja $\mathrm{v}$ ustanovah na to temo se izvajajo vsaj enkrat na dve leti. Tabela 1 kaže, da ima skoraj polovica zdravstvenega osebja bolečino v križu večkrat

Tabela 1: Pogostost pojavljanja bolečine v križu pri zdravstvenem osebju

Table 1: Prevalence of low back pain among health care personnel

\begin{tabular}{|c|c|c|c|c|c|c|c|c|}
\hline \multirow[b]{2}{*}{$\begin{array}{l}\text { Poklic, oddelek, starost/ } \\
\text { Profession, unit, age }\end{array}$} & \multirow[b]{2}{*}{$\begin{array}{c}\text { Vsi } \\
\text { All } \\
n \\
(\%) \\
\end{array}$} & \multicolumn{5}{|c|}{$\begin{array}{c}\text { Pogostost pojavljanja bolečine } v \text { križu/Frequency of low back pain } \\
n(\%)\end{array}$} & \multirow[b]{2}{*}{$\begin{array}{c}\text { Skupaj/ } \\
\text { Total } \\
(\%)\end{array}$} & \multirow[b]{2}{*}{$\begin{array}{l}\chi^{2} \\
(p)\end{array}$} \\
\hline & & $\begin{array}{c}\text { Še nisem } \\
\text { imel } \\
\text { bolečin v } \\
\text { križu/ } \\
\text { Never }\end{array}$ & $\begin{array}{c}\text { Večkrat na } \\
\text { mesec/ } \\
\text { Several } \\
\text { times/ } \\
\text { month }\end{array}$ & $\begin{array}{c}1 \times n a \\
\text { mesec/ } \\
1 x / \text { month }\end{array}$ & $\begin{array}{c}1-2 \times n a \\
\text { pol leta/ } \\
1-2 x / 6 \\
\text { months }\end{array}$ & $\begin{array}{c}\text { 1-2×na } \\
\text { leto/ } \\
1-2 x / \text { year }\end{array}$ & & \\
\hline Bolničarji & $\begin{array}{c}25 \\
(28,1)\end{array}$ & $\begin{array}{c}0 \\
(0,0)\end{array}$ & $\begin{array}{c}16 \\
(64,0)\end{array}$ & $\begin{array}{c}2 \\
(8,0)\end{array}$ & $\begin{array}{c}3 \\
(12)\end{array}$ & $\begin{array}{c}4 \\
(16,0)\end{array}$ & $25(100,0)$ & \multirow{3}{*}{$\begin{array}{c}27,73 \\
(0,001)\end{array}$} \\
\hline Medicinske sestre & $\begin{array}{c}40 \\
(44,9)\end{array}$ & $\begin{array}{c}1 \\
(2,5)\end{array}$ & $\begin{array}{c}19 \\
(47,5)\end{array}$ & $\begin{array}{c}11 \\
(27,5)\end{array}$ & $\begin{array}{c}3 \\
(7,5)\end{array}$ & $\begin{array}{c}6 \\
(15,0)\end{array}$ & $40(100,0)$ & \\
\hline Zdravniki & $\begin{array}{c}24 \\
(27,0)\end{array}$ & $\begin{array}{c}1 \\
(4,2)\end{array}$ & $\begin{array}{c}1 \\
(4,2)\end{array}$ & $\begin{array}{c}4 \\
(16,7)\end{array}$ & $\begin{array}{c}7 \\
(29,2)\end{array}$ & $\begin{array}{c}11 \\
(45,8)\end{array}$ & $24(100,0)$ & \\
\hline $\begin{array}{l}\text { Kirurški/ ortopedski } \\
\text { oddelek }\end{array}$ & $\begin{array}{c}25 \\
(28,1)\end{array}$ & $\begin{array}{c}1 \\
(4,0)\end{array}$ & $\begin{array}{c}7 \\
(28,0)\end{array}$ & $\begin{array}{c}4 \\
(16,0)\end{array}$ & $\begin{array}{c}1 \\
(4,0)\end{array}$ & $\begin{array}{c}12 \\
(48,0)\end{array}$ & $25(100,0)$ & \multirow{3}{*}{$\begin{array}{l}21,386 \\
(0,006)\end{array}$} \\
\hline $\begin{array}{l}\text { Interni/ intenzivni } \\
\text { oddelek }\end{array}$ & $\begin{array}{c}27 \\
(30,3)\end{array}$ & $\begin{array}{c}1 \\
(3,7)\end{array}$ & $\begin{array}{c}8 \\
(29,6)\end{array}$ & $\begin{array}{c}9 \\
(33,3)\end{array}$ & $\begin{array}{c}5 \\
(18,5)\end{array}$ & $\begin{array}{c}4 \\
(14,8)\end{array}$ & $27(100,0)$ & \\
\hline Negovalni oddelek & $\begin{array}{c}37 \\
(41,6)\end{array}$ & $\begin{array}{c}0 \\
(0,0)\end{array}$ & $\begin{array}{c}21 \\
(56,8)\end{array}$ & $\begin{array}{c}4 \\
(10,8)\end{array}$ & $\begin{array}{c}7 \\
(18,9)\end{array}$ & $\begin{array}{c}5 \\
(13,5)\end{array}$ & $37(100,0)$ & \\
\hline 19-34 let & $\begin{array}{c}47 \\
(52,8)\end{array}$ & $\begin{array}{c}2 \\
(4,3)\end{array}$ & $\begin{array}{c}19 \\
(40,4)\end{array}$ & $\begin{array}{c}9 \\
(19,1)\end{array}$ & $\begin{array}{c}7 \\
(14,9)\end{array}$ & $\begin{array}{c}10 \\
(21,3)\end{array}$ & $47(100,0)$ & \multirow{3}{*}{$\begin{array}{c}9,487 \\
(0,303)\end{array}$} \\
\hline $35-45$ let & $\begin{array}{c}29 \\
(32,6) \\
\end{array}$ & $\begin{array}{c}0 \\
(0,0) \\
\end{array}$ & $\begin{array}{c}11 \\
(37,9)\end{array}$ & $\begin{array}{c}8 \\
(27,6) \\
\end{array}$ & $\begin{array}{c}5 \\
(17,2) \\
\end{array}$ & $\begin{array}{c}5 \\
(17,2) \\
\end{array}$ & $29(100,0)$ & \\
\hline 46-57 let & $\begin{array}{c}13 \\
(14,6)\end{array}$ & $\begin{array}{c}0 \\
(0,0)\end{array}$ & $\begin{array}{c}3 \\
(46,2)\end{array}$ & $\begin{array}{c}0 \\
(0,0)\end{array}$ & $\begin{array}{c}1 \\
(7,7)\end{array}$ & $\begin{array}{c}6 \\
(46,2)\end{array}$ & $13(100,0)$ & \\
\hline
\end{tabular}

Legenda/Legend: $n$ - število odgovorov na trditev/number of replies to the argument; $\chi^{2}$ - vrednost testa hi-kvadrat/value of chisquare test; $p$ - vrednost statistične značilnosti/statistical significance value 
na mesec, večina jih ima enkrat do dvakrat na leto, sledijo tisti, ki jo imajo enkrat na mesec, manj kot desetino zdravstvenega osebja pa še ni imelo bolečine $v$ križu. Glede na poklic, ki ga opravljajo, ima kar več kot polovico bolničarjev in skoraj polovico medicinskih sester bolečine večkrat na mesec, sledijo zdravniki, ki imajo večinoma bolečino $\mathrm{v}$ križu enkrat do dvakrat na leto. Test $\chi^{2}$ je pokazal statistično značilne razlike $\mathrm{v}$ pojavnosti bolečine $\mathrm{v}$ križu pri zdravstvenem osebju glede na poklic, ki ga opravljajo, in sicer se bolečina v križu najpogosteje pojavlja pri bolničarjih, sledijo medicinske sestre, najmanj pogosta pa je bolečina $\mathrm{V}$ križu pri zdravnikih $(p=0,001)$.

Bolečina $\mathrm{v}$ križu se večkrat na mesec pojavlja pri zaposlenih na negovalnem oddelku, na ostalih oddelkih pa se pojavi manjkrat. Pri zaposlenih na internem in intenzivnem oddelku se najpogosteje pojavlja enkrat na mesec, na kirurškem/ortopedskem oddelku pa enkrat do dvakrat na leto. Test $\chi^{2}$ je pokazal statistično značilno razliko $\mathrm{v}$ pojavnosti bolečine $\mathrm{v}$ križu pri zdravstvenem osebju glede na oddelek, na katerem delajo, in sicer se bolečina $\mathrm{v}$ križu najpogosteje pojavlja na negovalnem oddelku $(p=0,006)$.

Tabela 2: Dejavniki delovnega mesta, ki so po mnenju anketirancev povezani z bolečino v križu pri zdravstvenem osebju Table 2: Work-related factors associated with the low back pain among health care personnel, according to respondents

\begin{tabular}{|c|c|c|c|c|c|c|c|c|}
\hline \multirow{2}{*}{$\begin{array}{l}\text { Dejavniki } \\
\text { delovnega } \\
\text { mesta/ } \\
\text { Work-related } \\
\text { factors }\end{array}$} & \multicolumn{4}{|c|}{$\begin{array}{c}\text { Poklic anketiranca/Respondent's } \\
\text { profession } \\
\bar{X}(s)\end{array}$} & \multicolumn{3}{|c|}{$\begin{array}{l}\text { Prisotnost bolečinv križu/ } \\
\text { Presence of low back pain } \\
\text { n(\%) }\end{array}$} & \multirow[b]{2}{*}{$\begin{array}{l}\chi^{2} \\
(p) \\
\end{array}$} \\
\hline & $\begin{array}{l}\text { Vsi/ } \\
\text { All }\end{array}$ & $\begin{array}{c}\text { Bolničar/ } \\
\text { Nurs. assistant }\end{array}$ & $\begin{array}{c}\text { Med. sestra/ } \\
\text { Nurse }\end{array}$ & $\begin{array}{c}\text { Zdravnik/ } \\
\text { Medical doctor }\end{array}$ & $F(p)$ & $\begin{array}{c}\text { Imajo boleč } \\
\text { v križu/ } \\
\text { Pain }\end{array}$ & $\begin{array}{l}\text { najo bolečine } \\
\text { v križu/ } \\
\text { No pain }\end{array}$ & \\
\hline $\begin{array}{l}\text { Stres na delovnem } \\
\text { mestu in doma }\end{array}$ & $\begin{array}{c}2,9 \\
(1,3)\end{array}$ & $\begin{array}{c}2,7 \\
(1,5)\end{array}$ & $\begin{array}{c}3,3 \\
(1,3)\end{array}$ & $\begin{array}{l}2,7 \\
(1,1)\end{array}$ & $\begin{array}{c}2,331 \\
(0,103)\end{array}$ & $\begin{array}{c}2,9 \\
(1,3)\end{array}$ & $\begin{array}{l}3,5 \\
(2,1)\end{array}$ & $\begin{array}{c}14,157 \\
(<0,001)\end{array}$ \\
\hline $\begin{array}{l}\text { Psihični napor na } \\
\text { delovnem mestu }\end{array}$ & $\begin{array}{c}3,1 \\
(1,4)\end{array}$ & $\begin{array}{l}2,8 \\
(1,7)\end{array}$ & $\begin{array}{c}3,6 \\
(1,3)\end{array}$ & $\begin{array}{l}2,5 \\
(0,9)\end{array}$ & $\begin{array}{c}6,656 \\
(<0,002)\end{array}$ & $\begin{array}{c}3,1 \\
(1,4)\end{array}$ & $\begin{array}{l}3,5 \\
(0,7)\end{array}$ & $\begin{array}{c}9,283 \\
(0,010)\end{array}$ \\
\hline $\begin{array}{l}\text { Premikanje } \\
\text { pacientov }\end{array}$ & $\begin{array}{c}4,2 \\
(0,9)\end{array}$ & $\begin{array}{c}4,2 \\
(0,9)\end{array}$ & $\begin{array}{c}4,4 \\
(1,0)\end{array}$ & $\begin{array}{c}4,0 \\
(0,7)\end{array}$ & $\begin{array}{c}1,308 \\
(0,276)\end{array}$ & $\begin{array}{c}4,3 \\
(0,8)\end{array}$ & $\begin{array}{l}2,0 \\
(0,0)\end{array}$ & $\begin{array}{c}3,032 \\
(0,220)\end{array}$ \\
\hline Stoječe delo & $\begin{array}{c}2,6 \\
(1,3)\end{array}$ & $\begin{array}{c}2,3 \\
(1,5)\end{array}$ & $\begin{array}{c}2,8 \\
(1,2)\end{array}$ & $\begin{array}{l}2,7 \\
(1,4)\end{array}$ & $\begin{array}{c}0,990 \\
(0,376)\end{array}$ & $\begin{array}{c}2,7 \\
(1,3)\end{array}$ & $\begin{array}{l}1,0 \\
(0,0)\end{array}$ & $\begin{array}{c}2,848 \\
(0,241)\end{array}$ \\
\hline Težko fizično delo & $\begin{array}{c}4,5 \\
(0,7)\end{array}$ & $\begin{array}{c}4,6 \\
(0,6)\end{array}$ & $\begin{array}{c}4,6 \\
(0,7)\end{array}$ & $\begin{array}{c}4,3 \\
(0,9)\end{array}$ & $\begin{array}{c}0,964 \\
(0,386)\end{array}$ & $\begin{array}{c}4,5 \\
(0,7)\end{array}$ & $\begin{array}{l}3,5 \\
(2,1)\end{array}$ & $\begin{array}{c}2,78 \\
(0,249)\end{array}$ \\
\hline $\begin{array}{l}\text { Dvigovanje in } \\
\text { prenašanje bremen }\end{array}$ & $\begin{array}{c}4,5 \\
(0,7)\end{array}$ & $\begin{array}{c}4,4 \\
(0,9)\end{array}$ & $\begin{array}{c}4,7 \\
(0,5)\end{array}$ & $\begin{array}{c}4,3 \\
(0,7)\end{array}$ & $\begin{array}{c}2,803 \\
(0,066)\end{array}$ & $\begin{array}{l}4,5 \\
(0,7)\end{array}$ & $\begin{array}{c}4,0 \\
(1,4)\end{array}$ & $\begin{array}{c}2,589 \\
(0,274)\end{array}$ \\
\hline Prisilna drža & $\begin{array}{c}3,4 \\
(1,3)\end{array}$ & $\begin{array}{c}3,2 \\
(1,1)\end{array}$ & $\begin{array}{c}3,3 \\
(1,3)\end{array}$ & $\begin{array}{c}3,8 \\
(1,5)\end{array}$ & $\begin{array}{c}1,245 \\
(0,293)\end{array}$ & $\begin{array}{c}3,4 \\
(1,3)\end{array}$ & $\begin{array}{l}2,5 \\
(0,7)\end{array}$ & $\begin{array}{c}2,548 \\
(0,280)\end{array}$ \\
\hline Sklanjanje & $\begin{array}{c}4,2 \\
(0,8)\end{array}$ & $\begin{array}{c}4,1 \\
(0,7)\end{array}$ & $\begin{array}{c}4,2 \\
(0,9)\end{array}$ & $\begin{array}{c}4,3 \\
(0,6)\end{array}$ & $\begin{array}{c}0,435 \\
(0,649)\end{array}$ & $\begin{array}{c}4,2 \\
(0,8)\end{array}$ & $\begin{array}{l}4,0 \\
(0,0)\end{array}$ & $\begin{array}{c}2,506 \\
(0,286)\end{array}$ \\
\hline $\begin{array}{l}\text { Slaba delovna } \\
\text { klima }\end{array}$ & $\begin{array}{c}2,6 \\
(1,3)\end{array}$ & $\begin{array}{c}2,3 \\
(1,3)\end{array}$ & $\begin{array}{c}2,9 \\
(1,4)\end{array}$ & $\begin{array}{c}2,6 \\
(1,1)\end{array}$ & $\begin{array}{c}1,538 \\
(0,221)\end{array}$ & $\begin{array}{l}2,6 \\
(1,3)\end{array}$ & $\begin{array}{l}3,5 \\
(2,1)\end{array}$ & $\begin{array}{c}2,235 \\
(0,327)\end{array}$ \\
\hline Pripogibanje & $\begin{array}{c}4,2 \\
(0,9)\end{array}$ & $\begin{array}{c}4,0 \\
(0,8)\end{array}$ & $\begin{array}{c}4,2 \\
(0,9)\end{array}$ & $\begin{array}{c}4,4 \\
(0,8)\end{array}$ & $\begin{array}{c}0,914 \\
(0,405)\end{array}$ & $\begin{array}{c}4,2 \\
(0,9)\end{array}$ & $\begin{array}{c}4,5 \\
(0,7)\end{array}$ & $\begin{array}{c}2,024 \\
(0,363)\end{array}$ \\
\hline $\begin{array}{l}\text { Nepravilna telesna } \\
\text { drža }\end{array}$ & $\begin{array}{c}4,2 \\
(0,9)\end{array}$ & $\begin{array}{c}4,0 \\
(0,9)\end{array}$ & $\begin{array}{c}4,3 \\
(1,0)\end{array}$ & $\begin{array}{c}4,3 \\
(0,7)\end{array}$ & $\begin{array}{c}1,046 \\
(0,356)\end{array}$ & $\begin{array}{c}4,2 \\
(0,9)\end{array}$ & $\begin{array}{c}4,0 \\
(1,4)\end{array}$ & $\begin{array}{c}1,869 \\
(0,393)\end{array}$ \\
\hline Veliko hoje & $\begin{array}{c}2,3 \\
(1,4)\end{array}$ & $\begin{array}{l}2,0 \\
(1,0)\end{array}$ & $\begin{array}{c}2,3 \\
(1,5)\end{array}$ & $\begin{array}{l}2,5 \\
(1,6)\end{array}$ & $\begin{array}{c}0,646 \\
(0,526)\end{array}$ & $\begin{array}{l}2,2 \\
(1,4)\end{array}$ & $\begin{array}{l}2,5 \\
(0,7)\end{array}$ & $\begin{array}{c}0,733 \\
(0,693)\end{array}$ \\
\hline Ponavljajoči se gibi & $\begin{array}{c}3,1 \\
(1,1)\end{array}$ & $\begin{array}{c}3,1 \\
(1,3)\end{array}$ & $\begin{array}{c}3,1 \\
(1,0)\end{array}$ & $\begin{array}{c}3,2 \\
(1,1)\end{array}$ & $\begin{array}{c}0,036 \\
(0,965)\end{array}$ & $\begin{array}{l}3,1 \\
(1,1)\end{array}$ & $\begin{array}{c}5,0 \\
(0,0)\end{array}$ & $\begin{array}{c}0,619 \\
(0,734)\end{array}$ \\
\hline $\begin{array}{l}\text { Ponavljajoči se } \\
\text { vzorci dela }\end{array}$ & $\begin{array}{c}4,0 \\
(0,9)\end{array}$ & $\begin{array}{c}3,9 \\
(0,9)\end{array}$ & $\begin{array}{c}4,1 \\
(0,9)\end{array}$ & $\begin{array}{c}3,8 \\
(0,9)\end{array}$ & $\begin{array}{c}0,982 \\
(0,379)\end{array}$ & $\begin{array}{l}4,0 \\
(0,9)\end{array}$ & $\begin{array}{l}3,5 \\
(0,7)\end{array}$ & $\begin{array}{c}0,432 \\
(0,806)\end{array}$ \\
\hline
\end{tabular}

Legenda/Legend: $n$ - število odgovorov na trditev/number of replies to the argument; $\chi^{2}$ - vrednost testa hi-kvadrat/value of chisquare test; $p$ - vrednost statistične značilnosti/statistical significance value; $-\bar{X}$ povprečna vrednost/average value; $s-$ standardni odklon/standard deviation; F - koeficient enofaktorske analize variance/one way ANOVA 
Bolečino v križu večkrat na mesec ima polovica anketiranih v mlajši starostni skupini, sledijo zdravstevni delavci v srednji starostni skupini in v starejši starostni skupini. Da še niso imeli bolečine v križu, je odgovorila manj kot desetina zdravstvenega osebja $\mathrm{v}$ mlajši starostni skupini. Enkrat na mesec ima bolečino $\mathrm{v}$ križu skoraj polovica zdravstvenega osebja $\mathrm{v}$ srednji starostni skupini in polovica $\mathrm{v}$ mlajši starostni skupini. Test $\chi^{2}$ ni pokazal statistično značilnih razlik $\mathrm{v}$ pojavnosti bolečine $\mathrm{v}$ križu pri zdravstvenem osebju glede na njihovo starost $(p=0,303)$.

Anketiranci so med dejavnike, ki so po njihovem mnenju najbolj povezani s pojavom bolečine $\mathrm{v}$ križu, uvrstili dejavnike na delovnem mestu, kot so težko fizično delo, dvigovanje in prenašanje bremen $(\bar{x}=$ $4,5)$, premikanje pacientov, sklanjanje, pripogibanje in nepravilna telesna drža $(\bar{X}=4,2)$ ter ponavljajoči se vzorci dela $(\bar{x}=4,0)$ (Tabela 2$)$. Dejavnika, ki sta po njihovem mnenju najmanj povezana $\mathrm{z}$ bolečino v križu, sta veliko hoje $(\bar{x}=2,3)$ in slaba delovna klima $(\bar{x}=2,6)$. Standardni odklon (tj. razpršenost $\mathrm{v}$ mnenjih anketiranih) se je gibal od 0,7 do 1,4. Največjo neenotnost $\mathrm{v}$ mnenju anketiranih $(s=1,4)$ smo ugotovili pri pripisovanju pomena dejavnikoma psihični napor na delovnem mestu in veliko hoje. Najbolj enotni pa so bili $(s=0,7)$ pri ocenjevanju vpliva dvigovanja in prenašanja bremen ter težkega fizičnega dela na delovnem mestu.
Dejavnik, ki je povezan s pojavom bolečine $\mathrm{v}$ križu in se statistično značilno razlikuje po mnenju zdravstvenega osebja glede na poklicno skupino, je psihični napor na delovnem mestu $(p<0,002)$. Zdravniki statistično značilno največji pomen $\mathrm{v}$ primerjavi $\mathrm{z}$ ostalima poklicnima skupinama pripisujejo dejavnikom pripogibanje $(\bar{X}=4,4, p=0,405)$, nepravilna telesna drža $(\bar{x}=4,3, p=0,356)$, dvigovanje in prenašanje bremen $(\bar{x}=4,3, p=0,066)$ in težko fizično delo $(\bar{x}=4,3$, $p=0,276)$. Medicinske sestre značilno največji pomen $\mathrm{v}$ primerjavi $z$ ostalima poklicnima skupinama pripisujejo dejavnikoma psihični napor na delovnem mestu $(\bar{X}=3,6, p<0,002)$ ter dvigovanje in prenašanje bremen $(\bar{x}=4,7, p=0,066)$. Bolničarji značilno največji pomen $\mathrm{v}$ primerjavi $z$ ostalima poklicnima skupinama pripisujejo dejavnikoma težko fizično delo $(\bar{x}=4,6, p=0,386)$ ter dvigovanje in prenašanje bremen $(\bar{x}=4,4, p=0,066)$.

Zdravstveno osebje, ki že ima bolečino v križu, je kot najpomembnejša dejavnika ocenilo dvigovanje in prenašanje bremen $(\bar{X}=4,5)$ ter težko fizično delo $(\bar{X}=4,5)$; pri teh dveh dejavnikih je bil standardni odklon tudi najmanjši $(s=0,7)$. Zdravstveno osebje brez bolečine v križu je kot najpomembnejši dejavnik ocenilo ponavljajoče se gibe $(\bar{X}=5,0)$ in pripogibanje $(\bar{X}=4,7)$. V odgovorih so bili anketirani povsem enotni pri ocenjevanju dejavnikov sklanjanje $(\bar{x}=4)$ in ponavljajoči se gibi $(\bar{X}=5)$, ki so jih vsi ocenili z enako povprečno oceno $(s=0,0)$.

Tabela 3: Demografski dejavniki in dejavniki zdravstvenega statusa, ki so po mnenju anketirancev povezani $z$ bolečino v križu pri zdravstvenem osebju

Table 3: Demographic factors and determinants of health associated with the low back pain among health care personnel, according to respondents

\begin{tabular}{|c|c|c|c|c|c|c|c|c|}
\hline \multirow{2}{*}{$\begin{array}{l}\text { Značilnosti } \\
\text { anketirancev/ } \\
\text { Respondents } \\
\text { determinats }\end{array}$} & \multicolumn{4}{|c|}{$\begin{array}{c}\text { Poklic anketiranca/ } \\
\text { Respondent's profession } \\
\bar{X} \\
(s)\end{array}$} & \multicolumn{3}{|c|}{$\begin{array}{c}\text { Prisotnost bolečine } v \text { križu/ } \\
\text { Presence of low back pain } \\
n \\
\%\end{array}$} & \multirow[b]{2}{*}{$\begin{array}{l}\chi^{2} \\
(p)\end{array}$} \\
\hline & $\begin{array}{l}\text { Vsi/ } \\
\text { All }\end{array}$ & $\begin{array}{l}\text { Bolničar/ } \\
\text { Nurs. } \\
\text { assistant }\end{array}$ & $\begin{array}{l}\text { Med. } \\
\text { sestra/ } \\
\text { Nurse }\end{array}$ & $\begin{array}{l}\text { Zdravnik/ } \\
\text { Medical } \\
\text { doctor }\end{array}$ & $\begin{array}{c}F \\
(p)\end{array}$ & $\begin{array}{l}\text { Imajo } \\
\text { bolečino v } \\
\text { križu/ } \\
\text { Pain }\end{array}$ & $\begin{array}{l}\text { Nimajo } \\
\text { bolečine v } \\
\text { križu/ } \\
\text { No pain }\end{array}$ & \\
\hline Telesna zgradba & $\begin{array}{c}3,3 \\
(1,0)\end{array}$ & $\begin{array}{c}2,6 \\
(1,0)\end{array}$ & $\begin{array}{l}3,3 \\
(1,0)\end{array}$ & $\begin{array}{c}3,9 \\
(0,5)\end{array}$ & $\begin{array}{c}12,851 \\
(<0,001)\end{array}$ & $\begin{array}{c}3,3 \\
(1,0)\end{array}$ & $\begin{array}{c}3,5 \\
(0,7)\end{array}$ & $\begin{array}{c}15,697 \\
(<0,001)\end{array}$ \\
\hline Nosečnost & $\begin{array}{c}3,4 \\
(1,4)\end{array}$ & $\begin{array}{c}2,4 \\
(1,6)\end{array}$ & $\begin{array}{c}3,8 \\
(1,2)\end{array}$ & $\begin{array}{c}3,6 \\
(1,1)\end{array}$ & $\begin{array}{c}8,964 \\
(<0,001)\end{array}$ & $\begin{array}{c}3,4 \\
(1,4)\end{array}$ & $\begin{array}{c}3,0 \\
(1,4)\end{array}$ & $\begin{array}{l}18,041 \\
(0,001)\end{array}$ \\
\hline Telesna teža & $\begin{array}{c}3,7 \\
(1,1)\end{array}$ & $\begin{array}{c}3,1 \\
(1,1)\end{array}$ & $\begin{array}{c}3,8 \\
(1,0)\end{array}$ & $\begin{array}{c}4,3 \\
(0,7)\end{array}$ & $\begin{array}{c}8,371 \\
(<0,001)\end{array}$ & $\begin{array}{c}3,7 \\
(1,1)\end{array}$ & $\begin{array}{c}4,5 \\
(0,7)\end{array}$ & $\begin{array}{l}11,505 \\
(0,003)\end{array}$ \\
\hline $\begin{array}{l}\text { Jemanje zdravil daljše } \\
\text { časovno obdobje }\end{array}$ & $\begin{array}{c}2,2 \\
(1,2)\end{array}$ & $\begin{array}{c}1,7 \\
(1,2)\end{array}$ & $\begin{array}{c}2,3 \\
(1,1)\end{array}$ & $\begin{array}{l}2,6 \\
(1,2)\end{array}$ & $\begin{array}{c}3,546 \\
(<0,033)\end{array}$ & $\begin{array}{c}2,2 \\
(1,2)\end{array}$ & $\begin{array}{c}1,0 \\
(0,0)\end{array}$ & $\begin{array}{c}5,095 \\
(0,078)\end{array}$ \\
\hline Kajenje & $\begin{array}{c}1,9 \\
(1,1)\end{array}$ & $\begin{array}{c}1,5 \\
(1,0)\end{array}$ & $\begin{array}{l}2,0 \\
(1,1)\end{array}$ & $\begin{array}{c}2,4 \\
(1,2)\end{array}$ & $\begin{array}{c}4,237 \\
(<0,018)\end{array}$ & $\begin{array}{c}2,0 \\
(1,1)\end{array}$ & $\begin{array}{c}1,0 \\
(0,0)\end{array}$ & $\begin{array}{c}4,633 \\
(0,099)\end{array}$ \\
\hline Spol & $\begin{array}{c}2,3 \\
(1,0)\end{array}$ & $\begin{array}{l}2,2 \\
(1,0)\end{array}$ & $\begin{array}{l}2,3 \\
(1,1)\end{array}$ & $\begin{array}{c}2,6 \\
(1,0)\end{array}$ & $\begin{array}{c}1,162 \\
(0,318)\end{array}$ & $\begin{array}{c}2,3 \\
(1,0)\end{array}$ & $\begin{array}{c}2,0 \\
(0,0)\end{array}$ & $\begin{array}{c}4,162 \\
(0,125)\end{array}$ \\
\hline Starost & $\begin{array}{c}3,1 \\
(1,3)\end{array}$ & $\begin{array}{c}2,7 \\
(1,4)\end{array}$ & $\begin{array}{c}3,1 \\
(1,2)\end{array}$ & $\begin{array}{c}3,5 \\
(1,3)\end{array}$ & $\begin{array}{c}2,800 \\
(0,066)\end{array}$ & $\begin{array}{c}3,1 \\
(1,3)\end{array}$ & $\begin{array}{c}1,5 \\
(0,7)\end{array}$ & $\begin{array}{c}3,346 \\
(0,188)\end{array}$ \\
\hline
\end{tabular}

Legenda/Legend: $n$-stevilo odgovorov na trditev/number of replies to the argument; $\chi^{2}$ - vrednost testa hi-kvadrat/value of chi-

square test; $p$ - vrednost statistične značilnosti/statistical significance value; $\boldsymbol{X}$ - povprečna vrednost/average value; s - standardni odklon/standard deviation; F - koeficient enofaktorske analize variance/one way ANOVA 
Anketirani menijo, da so med demografskimi dejavniki in dejavniki zdravstvenega statusa $\mathrm{Z}$ bolečino $\mathrm{v}$ križu najbolj povezani telesna teža $(\bar{x}=3,7)$, nosečnost $(\bar{x}=3,4)$ in telesna zgradba $(\bar{x}=3,3)$. Dejavniki, ki so po njihovem mnenju najmanj povezani $\mathrm{z}$ bolečino $\mathrm{v}$ križu, so kajenje $(\bar{X}=1,9)$, dolgotrajno jemanje zdravil $(\bar{X}=2,2)$ in spol $(\bar{X}=2,3)$. Največji standardni odklon $(s=1,4)$ je bil ugotovljen pri pripisovanju pomena dejavniku nosečnost, sledi dejavnik starost $(s=1,3)$ (Tabela 3$)$.

Dejavniki, ki so povezani s pojavom bolečine $\mathrm{v}$ križu in se statistično značilno razlikujejo po mnenju zdravstvenega osebja glede na poklicno skupino, so telesna zgradba $(p<0,001)$, telesna teža $(p<0,001)$, nosečnost $(p<0,001)$, kajenje $(p<0,018)$ in dolgotrajno jemanje zdravil $(p<0,033)$. Zdravniki statistično značilno največji pomen $\mathrm{v}$ primerjavi $\mathrm{z}$ ostalima poklicnima skupinama pripisujejo dejavnikom telesna zgradba $(\bar{x}=3,9, p<0,001)$, pomanjkanje gibalne aktivnosti $(\bar{x}=4,1, p<0,001)$ in telesna teža $(\bar{x}=4,3, p<0,001)$. Medicinske sestre značilno največji pomen $\mathrm{v}$ primerjavi $\mathrm{z}$ ostalima poklicnima skupinama pripisujejo dejavnikoma nosečnost $(\bar{X}=3,8, p<0,001)$ in telesna teža $(\bar{X}=3,8$, $p<0,001)$. Bolničarji značilno največji pomen $\mathrm{v}$ primerjavi $\mathrm{z}$ ostalima poklicnima skupinama pripisujejo dejavnikoma telesna teža $(\bar{x}=3,1, p<0,001)$ in telesna zgradba $(\bar{X}=2,6, p<0,001)$.

Zdravstveno osebje, ki že ima bolečino v križu, je kot najpomembnejša dejavnika ocenilo telesno težo $(\bar{x}=3,7, p>0,001)$ in nosečnost $(\bar{x}=3,4, p<0,001)$. Zdravstveno osebje brez bolečine $\mathrm{v}$ križu je kot najpomembnejša dejavnika ocenilo telesno težo $(\bar{X}=4,5, p=0,003)$ in telesno zgradbo $(\bar{X}=3,5$, $p<0,001)$; pri teh dveh dejavnikih je bil standardni odklon dokaj majhen $(s=0,7)$.

Tabela 4: Izvajanje izobraževanj in seminarjev na temo bolečine $v$ križu in pravilnega dvigovanja bremen $v$ zdravstvenih ustanovah

Table 4: Provision of education and seminars on the topic of back pain and proper heavy lifting in health care facilities

\begin{tabular}{|c|c|c|c|c|c|}
\hline \multirow[b]{2}{*}{$\begin{array}{l}\text { Izvajanje izobraževanj in seminarjev/ } \\
\text { Provision of education and seminars }\end{array}$} & \multicolumn{4}{|c|}{ Poklic/Profession n(\%) } & \multirow[b]{2}{*}{$\begin{array}{l}\chi^{2} \\
(p)\end{array}$} \\
\hline & $\begin{array}{c}\text { Bolničar/ } \\
\text { Nurs. assistant }\end{array}$ & $\begin{array}{l}\text { Med. sestra/ } \\
\text { Nurse }\end{array}$ & $\begin{array}{c}\text { Zdravnik/ } \\
\text { Medical } \\
\text { doctor }\end{array}$ & $\begin{array}{l}\text { Skupaj/ } \\
\text { All }\end{array}$ & \\
\hline Seminarji na to temo se ne izvajajo & $\begin{array}{c}8 \\
(21,6 / \\
32,0)\end{array}$ & $\begin{array}{c}10 \\
(27,0 / \\
25,0)\end{array}$ & $\begin{array}{c}19 \\
(51,4 / \\
79,2)\end{array}$ & $\begin{array}{c}37 \\
(41,6)\end{array}$ & \multirow{3}{*}{$\begin{array}{l}21,307 \\
(<0,001)\end{array}$} \\
\hline Seminarji se izvajajo zelo redko, $1 \mathrm{x}$ na 3 leta & $\begin{array}{c}5 \\
(22,7 / \\
20,0)\end{array}$ & $\begin{array}{c}14 \\
(63,6 / \\
35,0)\end{array}$ & $\begin{array}{c}3 \\
(13,6 / \\
12,5)\end{array}$ & $\begin{array}{c}22 \\
(24,7)\end{array}$ & \\
\hline $\mathrm{Da}$, izvajajo se seminarji vsaj $1 \mathrm{x}$ na 2 leti & $\begin{array}{c}12 \\
(40,0 / \\
48,0)\end{array}$ & $\begin{array}{c}16 \\
(53,3 / \\
40,0)\end{array}$ & $\begin{array}{c}2 \\
(6,7 / \\
8,3)\end{array}$ & $\begin{array}{c}30 \\
(33,7)\end{array}$ & \\
\hline
\end{tabular}

Legenda/Legend: $n$ - stevilo odgovorov na trditev/number of replies to the argument; $\chi^{2}$ - vrednost testa hi-kvadrat/value of chisquare test; $p$ - vrednost statistične značilnosti/statistical significance value; \% - odstotek/percentage

Tabela 4 prikazuje, da je večina vprašanih odgovorila, da se seminarji in izobraževanja o bolečini v križu in pravilnem dvigovanju bremen v zdravstveni ustanovi, kjer so zaposleni, ne izvajajo. Da se seminarji izvajajo vsaj enkrat na dve leti, je odgovorilo $33,7 \%$ anketiranih, da se seminarji izvajajo zelo redko (enkrat na tri leta ali manj), pa je odgovorilo dve desetini anketiranih. Test $\chi^{2}$ je pokazal statistično značilne razlike $\mathrm{v}$ mnenju treh poklicnih skupin $\mathrm{v}$ zdravstvu glede izvedbe izobraževanj in seminarjev na temo bolečine v križu. Zdravniki in medicinske sestre $\mathrm{v}$ večini menijo, da se seminarji na temo bolečine $\mathrm{v}$ križu in pravilnega dvigovanja bremen $\mathrm{v}$ njihovi ustanovi ne izvajajo oziroma se izvajajo zelo redko, medtem ko je skoraj polovica bolničarjev mnenja, da se $\mathrm{v}$ njihovi ustanovi izobraževanja na to temo izvajajo vsaj enkrat na dve leti $(p<0,001)$.

\section{Diskusija}

$\mathrm{V}$ raziskavi, ki smo jo izvedli med bolničarji, medicinskimi sestrami in zdravniki dveh zdravstvenih ustanov na Gorenjskem, je večina anketiranih bolničarjev in medicinskih sester odgovorila, da ima bolečino $\mathrm{v}$ križu večkrat na mesec, medtem ko se pri večini zdravnikov bolečina $\mathrm{v}$ križu pojavi do dvakrat na leto. Roupa s sodelavci (2008) je v raziskavi prišel do podobnih ugotovitev, saj je imela skoraj polovica vprašanih medicinskih sester že bolečino v križu. Prav tako je raziskava, ki jo je Karahan s sodelavci (2009) izvedel v Turčiji, pokazala, da je bolečina $\mathrm{v}$ križu najpogosteje prisotna ravno pri medicinskih sestrah, sledijo zdravniki in negovalno osebje.

Nekatere dosedanje raziskave (Zurc, 2012) so pokazale, da se bolečina $\mathrm{v}$ križu najpogosteje pojavi 
pri zaposlenih na ortopedskem oddelku. $\mathrm{Z}$ našo raziskavo smo prišli do različnih ugotovitev, saj je bolečina $v$ križu najpogostejša na negovalnem oddelku (večkrat na mesec), sledi pojavnost na internem in intenzivnem oddelku (do enkrat na mesec), najredkeje pa se bolečina $\mathrm{v}$ križu po naši raziskavi pojavlja na kirurškem in ortopedskem oddelku (največ dvakrat na leto). $\mathrm{V}$ raziskavi je sodelovalo 25 zaposlenih $\mathrm{s}$ kirurškega in ortopedskega oddelka, kar ne omogoča enakovredne primerjave in sklepanja za celotno populacijo zaposlenih na kirurškem in ortopedskem oddelku.

Avtorici Fortuna in Kersnič (2003) sta v raziskavi na vzorcu 65 operacijskih medicinskih sester ugotovili, da jeimelobolečino vkrižu večkot tričetrtine medicinskih sester, zaposlenih na intenzivnem oddelku, večina je bolečino občutila vsaj enkrat na mesec $\mathrm{V}$ primerjavi $\mathrm{z}$ omenjeno raziskavo smo $\mathrm{v}$ naši raziskavi, ki smo jo izvedli deset let kasneje, ugotovili večjo pojavnost bolečine $\mathrm{v}$ križu na internem in intenzivnem oddelku (pri več kot polovici anketirancev se je pojavljala vsaj enkrat na mesec ali večkrat na mesec).

Naša raziskava je pokazala, da je bolečina $\mathrm{v}$ križu pogostejša pri ženskah in zdravstvenem osebju $\mathrm{v}$ starostni skupini do 46 let, saj se pri skoraj polovici pojavlja večkrat na mesec. Prišli smo do podobnih ugotovitev kot Stričević s sodelavci (2006), ki menijo, da bolečina v križu najbolj ogroža medicinske sestre $\mathrm{v}$ starostni skupini od 20 do 40 let.

$\mathrm{Z}$ bolečino $\mathrm{v}$ križu so povezani mnogi dejavniki. Raziskave so pokazale (Brečko, et al., 2007; Karahan, et al., 2009; Douglas, et al., 2012), da so z bolečino pri zdravstvenem osebju najbolj povezani dejavniki dvigovanje bremen, sklanjanje in premikanje pacientov na delovnem mestu. Podobno smo ugotovili tudi v naši raziskavi, saj zdravstveno osebje $\mathrm{z}$ nastankom bolečine $\mathrm{v}$ ledvenem predelu hrbtenice najbolj povezuje dejavnike, kot so dvigovanje in prenašanje bremen, težko fizično delo, premikanje pacientov, sklanjanje, nepravilna telesna drža in ponavljajoči se vzorci dela pri delu $s$ pacientom. Bolničarji in medicinske sestre so bili precej enotni, kateri dejavniki so najbolj povezani z bolečino v križu, medtem ko so zdravniki za dejavnik, ki je močno povezan $z$ bolečino, označili tudi telesno težo. Ameriška študija (Wharton, et al., 2007) je pokazala, da je telesna teža dejavnik, ki je zelo povezan $\mathrm{z}$ bolečino v križu, saj se ob zmanjšanju čezmerne telesne teže izboljšajo človekove telesne funkcije, kar zmanjša bolečino $\mathrm{v}$ križu. $\mathrm{V}$ naši raziskavi smo ugotovili tudi, da zdravstveno osebje brez bolečine $\mathrm{v}$ križu za njen pojav pripisuje statistično značilno večji pomen telesni zgradbi, telesni teži, psihičnemu naporu, pomanjkanju gibalne aktivnosti in stresu v primerjavi z zdravstvenim osebjem z bolečino $\mathrm{v}$ križu. V raziskavi je Karahan s sodelavci (2009) ugotovil, da je večja razširjenost bolečine $\mathrm{v}$ križu pri zdravstvenem osebju povezana $\mathrm{z}$ večjo vključenostjo $\mathrm{v}$ pacientovo neposredno bližino. $\mathrm{V}$ raziskavi so prav tako dokazali, da je $\mathrm{z}$ bolečino $\mathrm{v}$ križu povezano kajenje. Zdravstveno osebje, ki smo ga anketirali v naši raziskavi, pa je ravno ta dejavnik označilo kot najmanj pomemben. Ugotovili smo, da zdravstveno osebje izpostavlja podobne dejavnike, ne glede na poklicno skupino, ki ji pripada.

Zdravstveno osebje smo vprašali, ali se $\mathrm{v}$ ustanovi, kjer so zaposleni, izvajajo izobraževanja in seminarji na temo bolečine $\mathrm{v}$ križu in pravilnega dvigovanja bremen. Skoraj polovica anketiranih je odgovorila, da se seminarji na to temo ne izvajajo oziroma se izvajajo zelo redko, boljše mnenje imajo bolničarji v primerjavi $\mathrm{z}$ ostalima preučevanima poklicnima skupinama. Leta 2010 so v eksperimentu (Carta, et al., 2010 cited in Zurc, 2012, p. 217), ki so ga izvedli med zdravstvenim osebjem, ugotovili, da simptome bolečine $\mathrm{v}$ križu zmanjšajo pravilne tehnike rokovanja $s$ pacientom, pravilna uporaba pripomočkov pri pacientu in znanje. Pograjc (2005) je izvedla raziskavo o izobraževanjih v Splošni bolnišnici Maribor in ugotovila, da se v ustanovi seminarji večinoma izvajajo redno. Poudariti je treba, da se je kljub temu, da se izobraževanja ne izvajajo, večina anketiranega zdravstvenega osebja opredelila, da se je o bolečini v križu in pravilnem dvigovanju bremen izobrazila ravno na organiziranih izobraževanjih $\mathrm{v}$ delovnem okolju. Ugotovili smo tudi, da je osebje z višjo izobrazbo svoje znanje o bolečini in križu pridobilo že v času formalnega šolanja za svoj poklic.

Izpostaviti velja, da dobljene ugotovitve veljajo za zdravstveno osebje v SBJ in DUFBJ in jih ni možno posploševati na celotno zdravstveno osebje v Sloveniji. $\mathrm{V}$ raziskavo smo vključili nenaključno izbran vzorec anketiranih, zaradi majhnega odziva anketirancev smo morali izvesti tudi drugi krog zbiranja podatkov. Kljub temu smo dobili nekaj pomembnih rezultatov, ki prikazujejo, da velik odstotek anketiranega zdravstvenega osebja trpi za bolečino v križu. Treba bi bilo izvesti nadaljnja raziskovanja na reprezentativnih vzorcih poklicnih skupin kot tudi zdravstvenih ustanov in tako ugotoviti, kako pogosta je bolečina $\mathrm{v}$ križu med zdravstvenim osebjem in kateri dejavniki so najbolj povezani z njenim nastankom. Prihodnje raziskave bi lahko preučile različne poklicne skupine, ki delujejo $\mathrm{v}$ zdravstvenih ustanovah, $\mathrm{v}$ raziskavo pa bi bilo treba vključiti tudi razne zdravstvene zavode in zdravstvene domove. Kot raziskovalno metodo velja uporabiti metodo opazovanja in na ta način ugotoviti pravilnost dvigovanja bremen in ustreznost uporabe ergonomskih pripomočkov zdravstvenih delavcev pri njihovem delu. Navedene ugotovitve so temeljna podlaga za izvedbo izobraževanja in seminarjev ter uvedbo novih pripomočkov, ki bi jih zdravstveno osebje uporabljalo pri svojem delu s pacientom.

\section{Zaključek}

Bolečina $\mathrm{v}$ križu je resen zdravstveni problem, ki se pojavlja $\mathrm{v}$ vseh poklicih in starostnih skupinah. $\mathrm{V}$ zdravstvu je bolečina $v$ križu povezana $\mathrm{z}$ neposrednim 
stikom $s$ pacientom, saj povečano tveganje za nastanek bolečine $\mathrm{v}$ križu predstavljajo dvigovanje in prenašanje bremen, premikanje pacientov, sklanjanje, pripogibanje in nepravilna telesna drža ob opravljanju dela s pacientom.

Naša raziskava je pokazala, da je bolečina $\mathrm{v}$ križu pogostejša pri bolničarjih, pogosteje se pojavlja na negovalnem oddelku in pri mlajšem zdravstvenem osebju, vendar traja dlje časa pri starejših, pri katerih je zaslediti tudi kronično bolečino $\mathrm{v}$ križu. Zdravstveno osebje v veliki meri deluje preventivno in skrbi za svojo gibalno aktivnost, najpogosteje se vprašani ukvarjajo s tekom in hojo. Da bi znali tudi na delovnem mestu skrbeti za svojo hrbtenico in tako preprečiti pojav bolečine $\mathrm{v}$ križu, je pomembno, da zdravstvene ustanove redno izvajajo seminarje in delavnice na temo bolečine $\mathrm{v}$ križu in pravilnega dvigovanja bremen.

Skrb za hrbtenico je velikega pomena in le z zdravim življenjskim slogom in izobraževanjem o preventivi pri delu bo zdravstveno osebje obvladalo bolečine $\mathrm{v}$ križu.

\section{Literatura}

Bilban, M. \& Djomba, J.K., 2007. Zdravstveni absentizem in bolezen gibal. Delo in varnost, 52(5), pp. 10-19.

Brečko, N., Gril, H. \& Zager, T., 2007. Prisotnost bolečine v hrbtenici zaradi obremenjenosti negovalnega osebja na delovnem mestu v domovih za starejše občane. Celje: Srednja zdravstvena šola Celje, pp. 34-39.

Douglas, E.H., Blorstad, A.L., McBrier, N.M., Denegar, C.R. \& Lengrich, E.J., 2012. Back pain among health care workers in Pennsylvania 2002-2006. Work, 41(1), pp. 93-98.

Fende, A., Polšak, M. \& Zupanc, P., 2009. Obremenjenost zdravstvenih delavcev na delovnem mestu. Celje: Srednja zdravstvena šola Celje, pp. 31-39.

Fortuna, T. \& Kersnič, P., 2003. Bolečine v križu pri operacijskih medicinskih sestrah. Obzornik zdravstvene nege, 37(3), pp. 199-206.

Karahan, A., Kav, S., Abbasoglu, A. \& Dogan, N., 2009. Low back pain: prevalence and associated risk factors among hospital staff. Journal of Advanced Nursing, 65(3), pp. 516-524. http://dx.doi.org/10.1111/j.1365-2648.2008.04905.x

PMid:19222649

Kert, S., 2012. Bolnik z bolečino v hrbtenici pri izbranem zdravniku. In: Vogrin, M. ed. Hrbtenica $v$ ortopediji: zbornik predavanj, Maribor, 9. november 2012. Maribor: Univerzitetni klinični center, Oddelek za ortopedijo, pp. 55-63.

Klančar, D. \& Kafel Jere, N., 2009. Bolnik z bolečinami v križu. In: Antolič, V. \& Vengust, A. eds. Hrbtenica: klinične poti zdravljenja: zbornik predavanj, Ljubljana, 13. februar 2009. Ljubljana: Ortopedska klinika, pp. 28-30.

Košak, R., 2010. Bolečina v ledvenem predelu hrbtenice. Rehabilitacija, 9(Suppl 2), pp. 3-8.

Pograjc, M., 2005. Raziskava motiviranja izvajalcev zdravstvene nege za izobraževanje in izpopolnjevanje v Splošni bolnišnici Maribor: diplomsko delo univerzitetnega študija. Kranj: Univerza v Mariboru, Fakulteta za organizacijske vede, pp. 48-61.

Ramšak, S., 2000. Izpostavljenost zdravstvenih delavcev. In: Ramšak, S. ed. Zbornik predavanj strokovnega srečanja medicinskih sester in zdravstvenih tehnikov, 22. september 2000. Celje: Splošna bolnišnica Celje, pp. 63-72.

Roupa, Z., Vassilopoulos, A., Sotiropoulou, P., Makrinika, E., Noula, M., Faros, E., et al., 2008. The problem of lower back pain in nursing staff and its effect on human activity. Health Science Journals, 2(4), pp. 219-225.

Stričević, J., Balantič, Z., Turk, Z. \& Čelan, D., 2006. Negativni pokazatelji zdravja kot posledica ergonomskih obremenitev na delovnem mestu medicinske sestre. In: Gazvoda, T.M. ed. Mednarodno posvetovanje Ergonomija: zbornik referatov Ljubljana, 21.-22. september 2006 (CD-ROM). Ljubljana: Visoka šola za zdravstvo, pp. 1-13.

Stričević, J., Balantič, Z., Turk, Z., Čelan, D., Kegl, B. \& Pajnkihar, M., 2012. Dejavniki tveganja za pojav bolečine v vratnem in ledvenem predelu hrbtenice pri negovalnem osebju v bolnišnici. Obzornik zdravstvene nege, 46(3), pp. 195-207.

Van Vuuren, B., Zinzen, E., van Heerden, H.J., Becker, P. \& Meensen, R., 2005. Psychosocial factors related to lower back problems in a South African manganese industry. Journal of Occupational Rehabilitation, 15(2), pp. 215-225.

http://dx.doi.org/10.1007/s10926-005-1220-1

PMid:15844678

Zurc, J., 2012. Povezave med gibalno aktivnostjo in pojavnostjo bolečine v križu pri zdravstvenem osebju. Zdravstveno varstvo, 51(3), pp. 207-222.

Wharton, J., Wharton, P. \& Browning, B., 2007. Za zdrav hrbet: znebite se bolečin $v$ hrbtu s preprostim revolucionarnim programom. Ljubljana: Mladinska knjiga.

\section{Citirajte kot/Cite as:}

Demšar, A., Zurc, J. \& Skela-Savič, B., 2016. Povezave med izbranimi dejavniki tveganja in pojavnostjo bolečine v križu pri zdravstvenem osebju. Obzornik zdrastvene nege, 50(1), pp. 57-64. http://dx.doi.org/10.14528/snr.2016.50.1.70 